\title{
Adsorption Characteristics and Potential of Olive Cake Alkali Residues for Biodiesel Purification
}

\author{
Mohammad Alnaief ${ }^{1, *}$, Arwa Sandouqa ${ }^{2}$, Ibrahem Altarawneh ${ }^{1} \mathbb{D}$, Mohammad Al-Shannag ${ }^{2} \mathbb{D}$, \\ Malek Alkasrawi ${ }^{3}$ (I) and Zayed Al-hamamre ${ }^{2, *}$
}

1 Department of Pharmaceutical and Chemical Engineering, Faculty of Applied Medical Sciences, German Jordanian University, Amman Madaba Street, Amman 11180, Jordan; Ibrahem.Altarawneh@gju.edu.jo

2 Chemical Engineering Department, School of Engineering, The University of Jordan, Amman 11942, Jordan; a.sandouqa@ju.edu.jo (A.S.); mohammad_al_shannag@hotmail.com (M.A.-S.)

3 UWSP Paper Science \& Engineering Department, University of Wisconsin, Stevens Point, WI 54481, USA; malkasra@uwsp.edu

* Correspondence: mohammad.alnaief@gju.edu.jo (M.A.); z.hamamre@ju.edu.jo (Z.A.-h.); Tel.: +962-797-456-333 (M.A.)

Citation: Alnaief, M.; Sandouqa, A.; Altarawneh, I.; Al-Shannag, M.; Alkasrawi, M.; Al-hamamre, Z. Adsorption Characteristics and Potential of Olive Cake Alkali Residues for Biodiesel Purification. Energies 2021, 14, 16. http:/ /dx.doi.org/10.3390/en14010016

Received: 15 November 2020 Accepted: 18 December 2020 Published: 22 December 2020

Publisher's Note: MDPI stays neutral with regard to jurisdictional claims in published maps and institutional affiliations.

Copyright: () 2020 by the authors. Licensee MDPI, Basel, Switzerland. This article is an open access article distributed under the terms and conditions of the Creative Commons Attribution (CC BY) license (https: / / creativecommons.org / licenses/by/4.0/).

\begin{abstract}
Mediterranean countries produce up to $97 \%$ of the total global olive production. Besides being a serious environmental burden, olive mill waste represents a potential resource of useful materials for recovery and valorization. In this work, the adsorption characteristics and potential of bioadsorbent material manufactured by alkali treatment of olive cake was evaluated. The resultant bioadsorbent was able to purify biodiesel to meets both ASTM D6751 and EN 14214 standards. Further, the sorption equilibrium was investigated at $25{ }^{\circ} \mathrm{C}$. Langmuir, Freundlich, and Temkin isotherms fit to the experimental data were evaluated by applying the non-linear Chi-square test. Freundlich and Temkin isotherms were shown to adequately described the adsorption isotherms of the produced bioadsorbent.
\end{abstract}

Keywords: bioadsorbent; biodiesel purification; olive cake; alkali treatment; adsorption isotherms

\section{Introduction}

Production of biodiesel from various lipids sources represents a clean-burning alternative to fossil fuel. Biodiesel is usually produced using transesterification/esterification reactions in which alcohol reacts with oils $\backslash$ fats in the presence of catalyst [1-3]. However, the produced biodiesel usually contains impurities that affect the biodiesel quality. These impurities include unreacted fats or oils, excess alcohols, traces of catalyst, glycerol, and soap $[4,5]$. The most popular method for biodiesel purification is wet washing where a large amount of water is consumed. The technical challenges of these methods are the extended production time, generation of a large amount of wastewater, and hence the increase of the process cost [6]. Further, the emulsion formed in wet purification reduces the biodiesel quality [7-11]. To solve these problems, the research has tended to focus on using dry purification using various techniques such as purification using membrane equipment such as inorganic microporous ceramic membranes [12], solid adsorbents such silica [13], activated carbon [14], magnesium silicate (magnesol) [15] and carbon fibers membranes [16], and organic adsorbents [17]. The main challenges for using such solid adsorbent are to reduce their production cost, develop easy methods for their recovery and recycling [5,15,18-21]. For example, magnesol and silica gel are non-recyclable Adsorbents, and thus, on large scale biodiesel production, several environmental and disposal problems rises when they are used [22]. On the other hand, treated agricultural residues have been suggested as potentially low cost biosorbent for biodiesel purification [23]. Previous studies examined the performance of spent tea waste [24], Cocoa Pod Husk [25], rice husk [26] 
and palm kernel shell [27]. These materials are renewable, inexpensive and non-toxic materials [28-30].

In the Mediterranean areas, olive mill waste is a major environmental burden [31-34]. The countries produce almost $97 \%$ of the total worldwide olive production $[35,36]$. The beneficiation of olive cake has been reported for many applications. In the work presented by Al-Widyan, et al., (2002), the potential of olive cake briquettes as an energy source was investigated [37]. In addition, activated carbon with a mesoporous structure was produced from the olive cake as reported by Gálvez-Pérez et al. [38]. Moreover, the hydrolysis of olive cake for a novel adsorbent production for copper removal was reported by FernándezGonzález [39]. Further, in previous work, lignin extracted from the olive cake was used to manufacture catalysts for biodiesel production [3].

The residues remaining after lignin removal represent an attractive material that can be used as biosorbent. This is because the isolation of lignin and hemicelluloses from lignocellulosic biomass enhanced the effective carboxylic groups, increase the internal surface area of the residues, and hence improved the adsorption efficiency [21,40-43].

Successful utilization of such residues for dry purification of biodiesel will not only represent a valorization of agricultural wastes but also produce comparable quality biodiesel at lower costs [44-46].

In the presented work, Bioadsorbent originated from delignified olive cake was produced and tested for biodiesel purification. The characteristics of purified biodiesel were analyzed following the international standards and compared with the traditional water washing purification method. Further, the spent adsorbent was regenerated and revaluated. The performance of the produced bioadsorbent for free fatty acid (FFA)and free glycerin removal was compared with some commercial and other bioadsorbents reported in the literature. Finally, three two-parameters equations, the Langmuir, Freundlich, and Temkin isotherms were utilized to model equilibrium sorption data of free fatty acids onto delignified olive cake alkyl residues. The non-linear Chi-square test was employed to assess the fit of the isotherms to the experimental equilibrium data.

\section{Materials and Methods}

\subsection{Biosorbent and Biodiesel Preparation}

The experiment was conducted in a heat jacketed agitated reactor. $100 \mathrm{~g}$ of olive cake was mixed with $600 \mathrm{~g}$ of $7.5 \mathrm{wt} . \% \mathrm{NaOH}$ solution. The reactor temperature was adjusted at $90{ }^{\circ} \mathrm{C}$ and the mixture was agitated for $90 \mathrm{~min}$. Residues from the alkali hydrolysis process were filtered and washed until the $\mathrm{pH}$ reached 7 . The collected solid material was dried at $105^{\circ} \mathrm{C}$ for 1 day. Three particle size cuts of the adsorbent were obtained by sieving: (90, 150, $250 \mu \mathrm{m})$ and were further used for biodiesel purification.

The structure, composition, and surface morphology of the adsorbent were presented in a previous publication [47]. Biodiesel was produced from waste vegetable oil (WVO). The detailed procedure for catalyst preparation and biodiesel production is available in previous work [3].

\subsection{Biodiesel Purification}

\subsubsection{Wet Purification}

This purification was performed in a separating funnel. The sample of the rough biodiesel was washed with an amount of water equal to 3 times the volume of the crud biodiesel used for the test. The wastewater layer (the bottom layer) was removed. After applying the washing for three times, the purified biodiesel was collected and dried gently to obtain the refined biodiesel.

\subsubsection{Dry Purification}

The dry purification was conducted in batch adsorption experiments in a $50 \mathrm{~mL}$ sealed flask equipped with an agitator. Various amounts of the adsorbent were used to investigate the removal of methanol, glycerol and other impurities. Several parameters 
were evaluated for the removal of methanol, glycerol, and other possible impurities. These parameters include: (1) the ratio of adsorbent to biodiesel $(0.5,1$, and 2 wt.\%), (2) adsorbent particle sizes (two cuts $\leq 90$, and $\leq 150$ microns), (3) adsorption time (10, 20, 30 , and $40 \mathrm{~min}$ ). After each test, the adsorbent was filtered and the produced biodiesel properties were recorded.

\subsection{Adsorption Isotherms}

For the adsorption isotherms study, in a $250 \mathrm{~mL}$ glass bottle, $100 \mathrm{~mL}$ of crude biodiesel solution was added into varying amounts of adsorbents $(0.25,0.5,0.75,1.00,1.25,1.5$, 1.75 , and $2 \mathrm{~g}$ ) with a stirring rate of $200 \mathrm{rpm}$. The temperature was kept at $25^{\circ} \mathrm{C}$ for $72 \mathrm{~h}$. Then, the adsorbent was removed by membrane filtration (Millipore filter, 0.45 micrometer). The oleic acid concentration was used to express the FFAs concentration. The equilibrium sorption data were presented as $\mathrm{mg}$ of FFAs adsorbed per $\mathrm{g}$ of bioadsorbent against FFAs residual concentration. The data were examined by non-linear forms of Langmuir, Freundlich, and Temkin isotherms.

\subsection{Oil and Biodiesel Characterization}

Table 1 presents the standard characterization methods employed to evaluate the physicochemical properties of the refined biodiesel samples.

Table 1. Standard Methods and Equipment Used for Physical Properties Measurements.

\begin{tabular}{|c|c|}
\hline Tested Property & Testing Procedure/Apparatus/Reference \\
\hline $\begin{array}{l}\text { Acid Value of biodiesel (mg KOH/g } \\
\text { oil) }\end{array}$ & ASTM D974-97 [48] \\
\hline Acid Value of WVO (mg KOH/g oil) & GB/T 5530-2005 [49] \\
\hline Density $\left(\mathrm{g} / \mathrm{cm}^{3}\right)$ & $\begin{array}{c}\text { Anton PAAR digital density meter DMA4100 } \\
\text { M, Graz, Austria }\end{array}$ \\
\hline Viscosity $(c \mathrm{P})$ & $\begin{array}{l}\text { ASTM test method D445 [50]/Fungilab } \\
\text { Viscometer TSML 210045, Barcelona, Spain }\end{array}$ \\
\hline Refractive Index & Abbe refractometer A83136 \\
\hline Iodine value (g iodine/100 g sample) & ASTM D1959-97 (1997) [51] \\
\hline Peroxide value (meq $\mathrm{O}_{2} / \mathrm{kg}$ oil) & IUPAC 2.501 (1992) [52] \\
\hline Saponification value (mg KOH/g oil) & ASTM D1962-85 (1995) [53] \\
\hline Free glycerin $(\mathrm{mg} / \mathrm{kg})$ & UV-Visible Spectrophotometer, Kent, UK [54] \\
\hline Ash content & TAPPI T211 om-07 [55] \\
\hline lignin content as Kalson lignin & ASTM: E1721-01 (2010) [56] \\
\hline Moisture content & (Vicentim et al., 2010) [57] \\
\hline
\end{tabular}

\subsection{Isotherm Modeling}

\subsubsection{Langmuir Isotherm Model}

Langmuir isotherm describes the formation of monolayer adsorption at the outer surface of the adsorbent, with the assumption that the adsorbate does not transmigrates in the plane of the surface. Therefore, the model can be used for surfaces containing a finite number of identical sites where monolayer adsorption takes place. Accordingly, the amount of adsorbent is expressed in Sarioglu et al. work [58]:

$$
\mathrm{q}_{\mathrm{e}}=\mathrm{q}_{\max } \mathrm{K}_{\mathrm{a}} \frac{\mathrm{C}_{\mathrm{e}}}{1+\mathrm{K}_{\mathrm{a}} \mathrm{C}_{\mathrm{e}}}
$$

where $\mathrm{q}_{\mathrm{e}}\left(\mathrm{mg} \cdot \mathrm{g}^{-1}\right)$ is the adsorbed equilibrium amount, $\mathrm{q}_{\max }\left(\mathrm{mg} \cdot \mathrm{g}^{-1}\right)$ is the maximum amount of FFA per unit adsorbent, $\mathrm{K}_{\mathrm{a}}\left(\mathrm{L} \cdot \mathrm{mg}^{-1}\right)$ is Langmuir constant, and $\mathrm{C}_{\mathrm{e}}\left(\mathrm{mg} \cdot \mathrm{L}^{-1}\right)$ is the equilibrium liquid-phase concentration. 


\subsubsection{Freundlich Isotherm Model}

The Freundlich model is an empirical expression representing the isothermal variation of adsorption between a fluid (liquid or gas) and the surface of a solid material. It considers heterogeneous adsorptive energies on the adsorbent surface. It is expressed as (Freundlich, 1909):

$$
\mathrm{q}_{\mathrm{e}}=\mathrm{K}_{\mathrm{f}} \mathrm{C}_{\mathrm{e}}^{1 / \mathrm{n}}
$$

where $C_{e}\left(m g \cdot L^{-1}\right)$ is the equilibrium liquid-phase concentration, $K_{f}\left(m g \cdot g^{-1}\right)$ is Freundlich constants, and the dimensionless $\mathrm{n}$ is the intensity [58].

\subsubsection{Temkin Isotherm}

Because of adsorbent- adsorbate interactions, Temkin model assumes a linear reduction of the molecules' heat of adsorption with a surface coverage of the layer. A uniform binding energies distribution is considered up to some maximum value of binding energy [59].

The model equation is expressed as

$$
\mathrm{q}_{\mathrm{e}}=\frac{\mathrm{RT}}{\mathrm{b}_{\mathrm{T}}} \ln \left(\mathrm{A}_{\mathrm{T}} \mathrm{C}_{\mathrm{e}}\right)
$$

where $\mathrm{A}_{\mathrm{T}}\left(\mathrm{L} \cdot \mathrm{g}^{-1}\right)$ is the Temkin adsorption potential, $\mathrm{b}_{\mathrm{T}}$ is Temkin isotherm constant, $\mathrm{R}$ is the universal gas constant $\left(8.314 \mathrm{~J} \cdot \mathrm{mol}^{-1} \cdot \mathrm{K}^{-1}\right), \mathrm{T}$ is the temperature at $298 \mathrm{~K}, \mathrm{C}_{\mathrm{e}}\left(\mathrm{mg} \cdot \mathrm{L}^{-1}\right)$ is the equilibrium liquid-phase concentration, and $\mathrm{B}=\mathrm{RT} / \mathrm{b}_{\mathrm{T}}$ is a constant related to the heat of sorption $\left(\mathrm{J} \cdot \mathrm{mol}^{-1}\right)$.

\subsection{Statistical and Error Analysis}

In this study, an optimization procedure based on the non-linear Chi-square test was employed to assess the fit of the used isotherms to the equilibrium data. The solver add-in with Microsoft's spreadsheet was used. The mathematical statement of the test is represented as (Ho, et al., 2005).

$$
x^{2}=\sum \frac{\left(q_{e}-q_{e, m}\right)^{2}}{q_{e, m}}
$$

where $\mathrm{q}_{\mathrm{e}, \mathrm{m}}\left(\mathrm{mg} \cdot \mathrm{g}^{-1}\right)$ is the equilibrium capacity calculated from the model, and $\mathrm{q}_{\mathrm{e}}\left(\mathrm{mg} \cdot \mathrm{g}^{-1}\right)$ is the equilibrium capacity obtained from the experimental data. In the case of the similarity between the calculated and obtained data, $\chi^{2}$ would be a small number. Consequently, Chi-square test is used to approve the best-fit isotherm for the used sorption system.

All experimental data were conducted at least in triplicate. The average and standard deviation were presented.

\section{Results and Discussion}

\subsection{WVO and Crude Biodiesel Properties}

Table 2 shows the characteristic properties of WVO and crude biodiesel along with dry and wet purification. As can be seen, the acid value of the crude biodiesel was smaller than that tabulated at the ASTM and European Standards $(0.315 \mathrm{mg} \mathrm{KOH} / \mathrm{g})$. Moreover, the measured kinematic viscosity $\left(7.5 \mathrm{~mm}^{2} / \mathrm{s}\right)$ was higher than the acceptable limits reported in ASTM standard for biodiesel at $40^{\circ} \mathrm{C}$.

The effect of adsorption time on FFA removal and free glycerin removal after the purification process using two different absorbent sizes and for different adsorbent dosages are shown in Figure 1a,b and Figure 2a,b respectively. It can be noticed that the adsorbent dosage and adsorbent particle size affected significantly the removal of FFA and the free glycerin. The FFA and glycerin removals increased with time and by increasing the adsorbent dosage and decreasing the adsorbent particle size. The addition of $2.0 \%$ by 
weight alkali residues (particle sizes $<90 \mu \mathrm{m}$ ) on biodiesel resulted in an excellent removal of the FFA at $29.8 \%$.

Table 2. Waste vegetable oil, crude biodiesel, alkali residue, and water washing purified biodiesel.

\begin{tabular}{ccccccc}
\hline Biodiesel Property & Oil & $\begin{array}{c}\text { Crude } \\
\text { Biodiesel }\end{array}$ & $\begin{array}{c}\text { Alkali } \\
\text { Residue }\end{array}$ & $\begin{array}{c}\text { Water } \\
\text { Washing }\end{array}$ & $\begin{array}{c}\text { ASTM 6751 } \\
\mathbf{( 2 0 0 2 )}\end{array}$ & $\begin{array}{c}\text { EN 14214 } \\
\mathbf{( 2 0 1 3 )}\end{array}$ \\
\hline Yield $\%$ & - & 93 & 89 & - & - & \\
Acid Value $(\mathrm{mg} \mathrm{KOH} / \mathrm{g})$ & 3.67 & 0.32 & 0.23 & 0.28 & 0.80 max & 0.50 max. \\
Peroxide Value $(\mathrm{meq} / \mathrm{Kg})$ & 33.6 & 29.6 & 29.0 & 29.0 & - & - \\
Iodine Value $\left(\mathrm{g} \mathrm{I}_{2} / 100 \mathrm{~g}\right)$ & 112.3 & 20.4 & 19.6 & 19.6 & - & 120.0 max. \\
Saponification Value $(\mathrm{mg} \mathrm{KOH} / \mathrm{g})$ & 201 & 180 & 146 & 151 & - & - \\
Soap and Catalyst $(\mathrm{ppm})$ & 0 & 0 & 0 & 0 & - & 5 max. \\
RI & 1.480 & 1.457 & 1.454 & 1.457 & - & - \\
Density $\left(\mathrm{g} / \mathrm{cm}^{3}\right) \pm 0.0001$ & 0.92 & 0.88 & 0.89 & 0.89 & - & $0.86-0.9$ \\
Kinematic viscosity \pm 0.01 & 22.4 & 7.5 & 4.0 & 5.5 & $1.9-6.0$ & - \\
$\left(\mathrm{mm}^{2} / \mathrm{sec}\right)$ at $40{ }^{\circ} \mathrm{C}$ & - & 0.01 & 0.00 & 0.00 & $0.02 \%$ max & - \\
Free glycerin $(\mathrm{mg} / \mathrm{kg})$ & - & & & & &
\end{tabular}

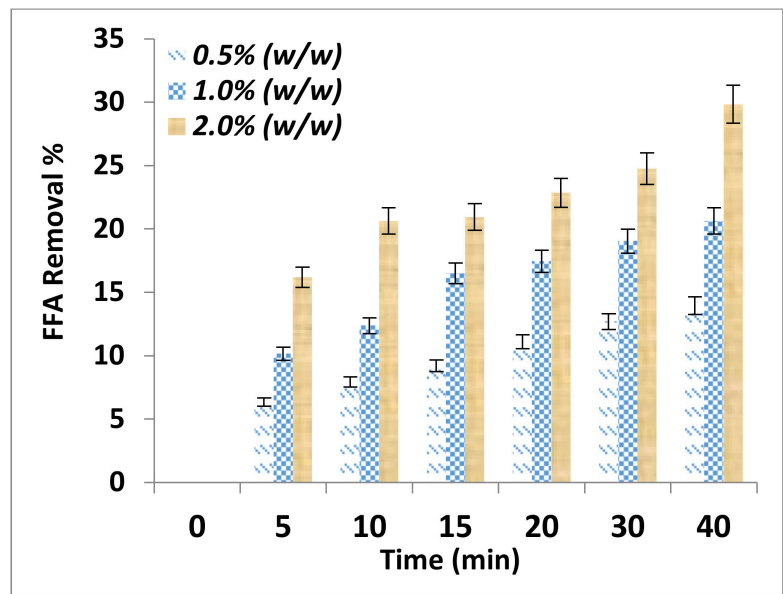

(a)

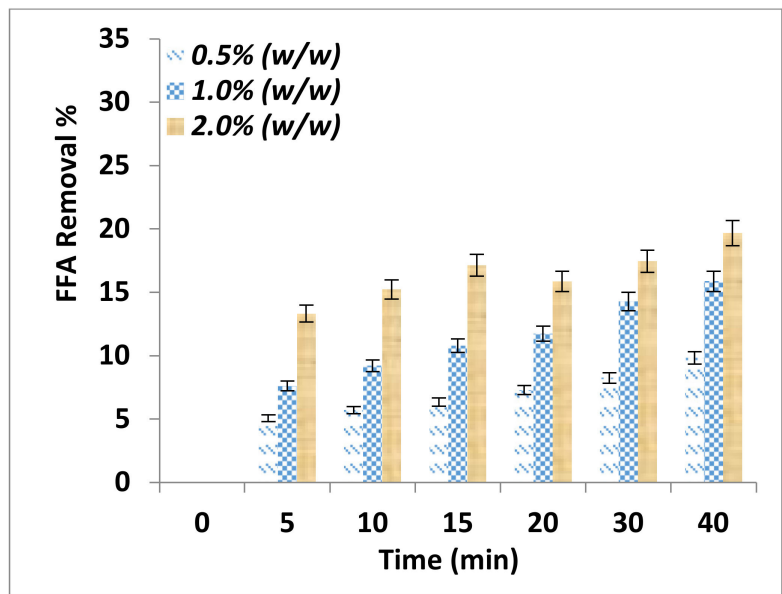

(b)

Figure 1. FFA removal as a function of adsorption time for various adsorbent dosage (a) Particle sizes $\leq 90 \mu \mathrm{m}$ (b) Particle size of $\leq 150 \mu \mathrm{m}$.

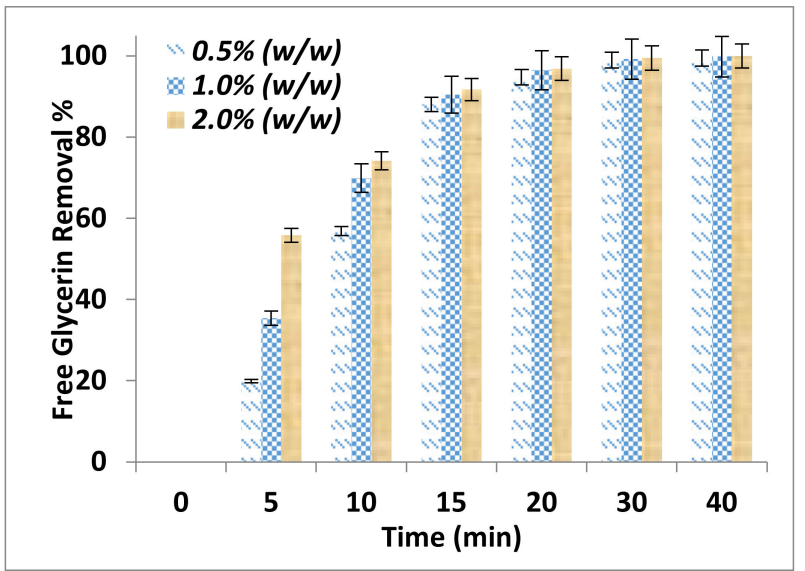

(a)

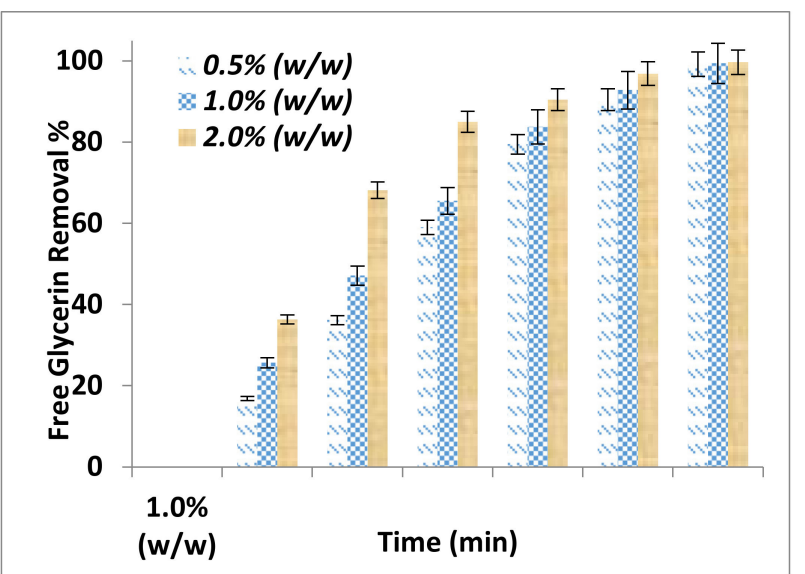

(b)

Figure 2. Effect of adsorption time on free glycerin removal for different adsorbent dosage (a) Particle sizes $\leq 90 \mu \mathrm{m}(\mathbf{b})$ Particle size of $\leq 150 \mu \mathrm{m}$. 
Further, the comparison between the purification parameters showed that $2.0 \%$ by weight alkali residues with particle size $\leq 90 \mu \mathrm{m}$ removed completely the free glycerin and after $30 \mathrm{~min}$ adsorption time. This is because of a strong interaction between the alkali delignified olive cake and the polar compounds. However, for the particle $\leq 150 \mu \mathrm{m}$, complete removal was achieved at $40 \mathrm{~min}$ adsorption time. This can be explained considering that particle sizes $\leq 90 \mu \mathrm{m}$ will have a larger surface area than those of $\leq 150 \mu \mathrm{m}$ in size.

A summary of biodiesel properties after the purification processes are shown in Table 2 . The values are measured for $2 \%$ adsorbent loading with a particle sizes of less than $900 \mu \mathrm{m}$ at 40 min contact time. FFA removal along with other impurities has significantly reduced the kinematic viscosity of the crude biodiesel from $7.5 \mathrm{~mm}^{2} / \mathrm{s}$ to $4 \mathrm{~mm}^{2} / \mathrm{s}$. This value satisfies the specifications presented in the ASTM and European standards. However, the density of biodiesel after purification was $0.8860 \mathrm{~g} / \mathrm{cm}^{3}$ and higher than that of the crude biodiesel. A possible explanation is the removal of methanol residues that remained after separation. Though, the value satisfies the EN 14214 standards. further, the properties of the water washed purified samples (acid value, density, and viscosity) were higher than those purified with alkali residue.

Comparing the results obtained in this work using alkali-treated adsorbent, the use of spent tea-activated carbon presented by Fadhil et al. higher yield and more refined biodiesel as shown in Table 3. On the other hand, similar results in terms of yield and adsorption efficiency were obtained compared to those obtained by silica gel [24]. At the same time, the fuel properties were better than the properties reported by Fadhil and Abdulahad for biodiesel purified using de-oiled activated carbon [60].

Table 3. Purified biodiesel properties using different bioadsorbents compared to water washing and the bioadsorbent in this work.

\begin{tabular}{|c|c|c|c|c|c|c|}
\hline \multirow[t]{2}{*}{ Property } & $\begin{array}{c}\text { Spent Tea } \\
\text { Activated } \\
\text { Carbon }\end{array}$ & Silica Gel & $\begin{array}{c}\text { Water } \\
\text { Washing }\end{array}$ & $\begin{array}{l}\text { De-Oiled } \\
\text { Cake } \\
\text { (Mustard } \\
\text { Seeds) }\end{array}$ & $\begin{array}{c}\text { Water } \\
\text { Washing }\end{array}$ & \multirow{2}{*}{$\begin{array}{c}\text { Alkali } \\
\text { Residue } \\
\text { This Study } \\
\end{array}$} \\
\hline & \multicolumn{3}{|c|}{ (Fadhil, et al., 2012) } & \multicolumn{2}{|c|}{ (Freundlich, 1909) } & \\
\hline Yield\% & 97 & 93 & 88 & 94 & 84 & 93 \\
\hline Density $\left(\mathrm{g} / \mathrm{cm}^{3}\right)$ & 0.8755 & 0.8800 & 0.8920 & 0.8889 & 0.8995 & 0.8860 \\
\hline $\begin{array}{c}\text { Viscosity }\left(\mathrm{mm}^{2} / \mathrm{s}\right) \text { at } \\
40{ }^{\circ} \mathrm{C}\end{array}$ & 2.6 & 3.2 & 3.3 & 5.3 & 8.3 & 4.0 \\
\hline $\begin{array}{l}\text { Acid value (mg } \\
\mathrm{KOH} / \mathrm{g})\end{array}$ & 0.092 & 0.247 & 0.301 & 0.186 & 0.331 & 0.232 \\
\hline $\mathrm{RI}$ at $20^{\circ} \mathrm{C}$ & 1.445 & 1.448 & 1.457 & 1.451 & 1.457 & 1.454 \\
\hline $\mathrm{SV}$ (mg KOH/g) & - & - & - & 201 & 203 & 146 \\
\hline IV (mg I $\left.\mathrm{I}_{2} / 100 \mathrm{~g}\right)$ & - & - & - & 104 & 105 & 20 \\
\hline
\end{tabular}

\subsection{Comparison of Biodiesel Purification Using Olive Cake Alkyl Residues with Other Adsorbents}

Figure 3 shows a comparison between the \% removal of FFA and free glycerin obtained in this study using olive cake alkyl residues (particle sizes of $150 \mu \mathrm{m}$ ) and other commercial and biomass-based adsorbents. It can be observed that olive cake alkyl residues properties reduced the glycerin content to a very low value achieving 99.7\% removal. These results are similar to the value achieved in [28] using 5\% potato starch, 1-2\% cassava starch, and 1\% rice starch. Although the \% removal of glycerin using $\mathrm{ZnCl}_{2}$-rice husk activated carbon (2 wt.\%) [61] was similar to the value achieved in this work, the former resulted in biodiesel with dark color. Further, the performance of olive cake alkyl residues as adsorbents was even better than the performance of several biomass adsorbents and commercial adsorbents that had been used for the same purpose such as rice husk ash and magnesol [62], oil palm empty fruit bunch, silica gel and bentonite [63], Sugarcane Bagasse [64]. 


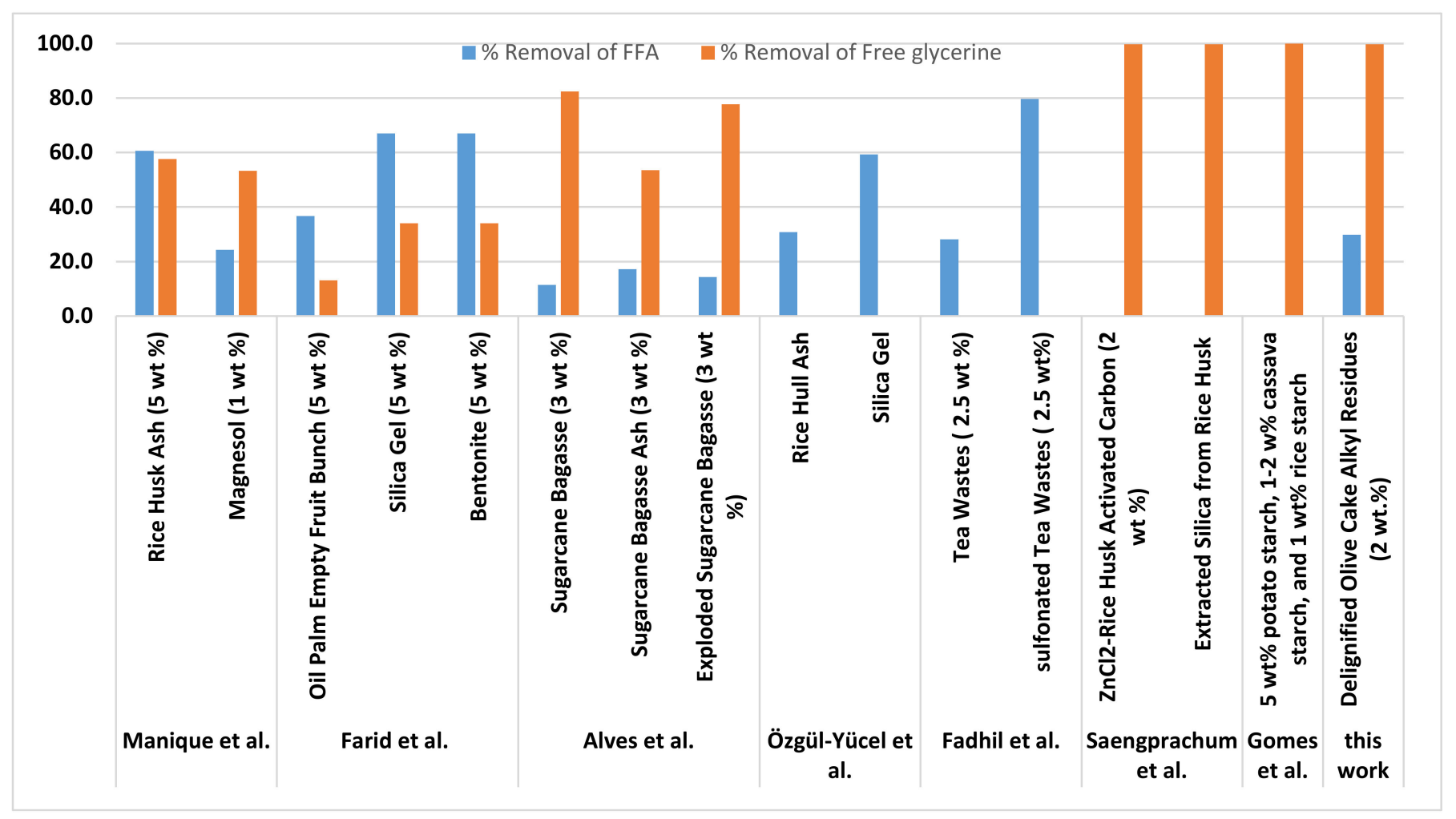

Figure 3. Comparison between the \% removal of FFA and free glycerin obtained in this study using olive cake alkyl residues (particle sizes of $150 \mu \mathrm{m}$ ) and other commercial adsorbents and biomass-based adsorbents.

Considering FFA removal, olive cake alkyl residues (particle sizes of $150 \mu \mathrm{m}$ ) was able to accomplish $29.8 \%$ removal of FFA. Its performance was comparable with tea wastes [65], rice hull ash [66], and magnesol [62]. However, higher FFA removal was achieved with silica gel [66], sulfonated tea wastes [65] rice husk ash [62], silica gel, bentonite, and oil palm empty fruit bunch [63].

\subsection{Reusability of the Adsorbent}

The durability of the produced bioadsorbent samples was evaluated. The test was performed for particle sizes $\leq 90 \mu \mathrm{m}$ with $2 \mathrm{wt}$.\% bioadsorbent dosage and $40 \mathrm{~min}$ adsorption time. The results presented in Figure 4 showed that the adsorption capacity decreased and reached about $50 \%$ of its starting activity after the 15 th cycle. Nevertheless, the activity of the spent adsorbent was restored after activation.

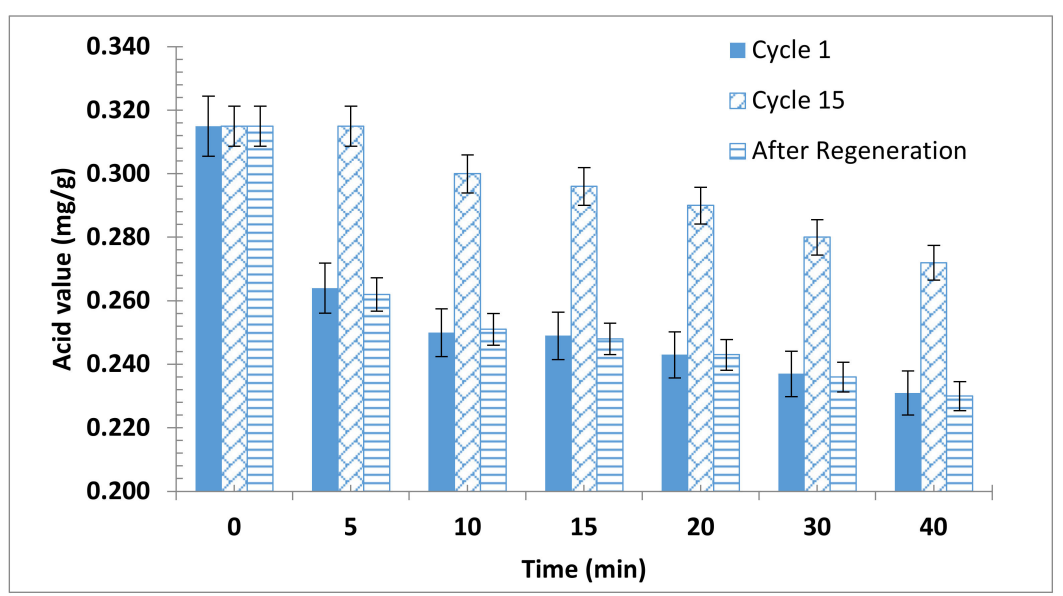

Figure 4. Bioadsorbent recyclability. 
Unfortunately, little work was reported concerning the regeneration and reusability of biomass-based adsorbents. Saengprachum et al. reported that extracted silica from rice husk ash can be regenerated and can be reused up to 5 times [61]. On the other hand, the durability of the olive cake alkyl residues as adsorbent was extremely higher than the durability of extracted silica

\subsection{Adsorption Isotherms}

The isotherms in this work described the FFA adsorbed on the surface of the produced bioadsorbent. Since all the used models are non-linear, the non-linear regression method must be applied to calculate the model's parameters using an optimization program. However, linearized forms of different models present a simple approach to obtain the model's parameters in comparison to complex optimization programs. The analysis performed by (Subramanyam, and Das, 2014) showed that the overall mean of the error functions of non-linear models is considerably smaller compared to their linearized counterparts, and thus non-linear modeling can represent the experimental results much better than the linearized ones [67]. Also, Salihi, et al. concluded that using the experimental data to get the isotherm parameters using the non-linear method is the most suitable approach [68]. Further, the study of Bolster et al. confirmed that the use of the linearized forms of the Langmuir isotherm to calculate the isotherm parameters restrict the ability to model the adsorption data with reasonable accuracy [69]. This is due to the fact that various linear forms of the Langmuir equation significantly affect the calculations of the model parameters [70]. The linearization method of the nonlinear equation will results in different outcomes for different linearization forms due to the difference in the error structure that would get varied upon [71]. Besides, when adsorption data do not comply to the standard Langmuir model, the linearized model fits transformed data may not be clear [72]. Therefore, to avoid such errors, the non-linear Chi-square analysis method shall be used $[73,74]$

To investigate the capability of the used isotherms describing the experimental results, the theoretical plots from each isotherm have been fitted with the experimental data for adsorption of FFA on the alkali residue adsorbent. The Chi-square statistic, $\chi^{2}, \mathrm{R}^{2}$, and model parameters were obtained and are shown in Table 4. For the Langmuir isotherm model, the solution did not converge when a non-negativity constraint for $\mathrm{K}_{\mathrm{a}}$ values was provided in the solver. On the contrary, the model equation fits the data with a negative value for $K_{a}$. Hence, this trend confirms that Langmuir isotherm fails to describe the adsorption process. On the other hand, there was a convergence of the parameters derived from the non-linear Freundlich and non-linear Temkin isotherms.

Table 4. The Chi-square statistic, $\chi^{2}, \mathrm{R}^{2}$, and isotherm models parameters.

\begin{tabular}{|c|c|c|c|}
\hline $\begin{array}{l}\text { Non-Linearized } \\
\text { Isotherm }\end{array}$ & Model Parameters & $x^{2}$ & $\mathbf{R}^{2}$ \\
\hline $\begin{array}{l}\text { Langmuir } \\
\mathrm{q}_{\mathrm{m}}(\mathrm{mg} / \mathrm{g}) \\
\mathrm{K}_{\mathrm{a}}(\mathrm{L} / \mathrm{mg})\end{array}$ & \multicolumn{3}{|c|}{ Not applicable (Non-positive $\mathrm{K}_{\mathrm{a}}$ ) } \\
\hline $\begin{array}{c}\text { Freundlich } \\
K_{f}\left(\mathrm{~L}^{5.365} / \mathrm{g}\right. \\
\text { adsorbent }) \\
\mathrm{n}\end{array}$ & $\begin{array}{c}2.076 \times 10^{-11} \\
0.186\end{array}$ & 0.203 & 0.955 \\
\hline $\begin{array}{c}\text { Temkin } \\
\mathrm{b}_{\mathrm{T}}(\mathrm{J} / \mathrm{mol} \cdot \mathrm{K}) \\
\mathrm{A}_{\mathrm{T}}(\mathrm{L} / \mathrm{g})\end{array}$ & $\begin{array}{c}125.957 \\
0.0098\end{array}$ & 0.466 & 0.892 \\
\hline
\end{tabular}

Figure 5 shows the experimental data for adsorption of FFA on the produced bioadsorbent along with the empirical Freundlich and the Temkin isotherm at a temperature of 293 K. It was clear that both two-parameters Temkin and Freundlich isotherms were the fitting models for the experimental results. However, when the two models were com- 
pared, the Freundlich isotherm model has a lower $\chi^{2}$ than the Temkin model. Therefore, Freundlich isotherm seemed to be the best-fitting model for the chosen sorption system.

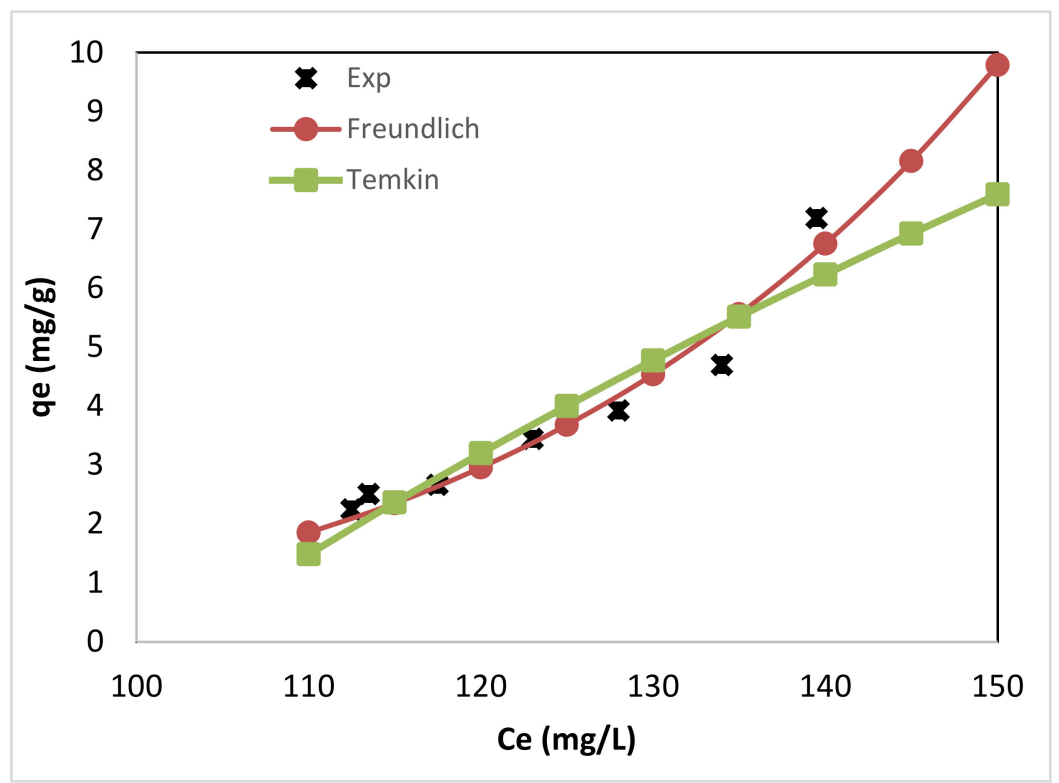

Figure 5. Comparing the empirical Freundlich and the Temkin isotherm with the experimental data for adsorption of FFA on the alkali residue adsorbent, at a temperature of $293 \mathrm{~K}$.

Non-conformation of the data into a Langmuir adsorption isotherm model and fitting of the data to the Freundlich isotherm model suggested a heterogeneous and nonuniform sorbent surface. Further, this is an indication of the multilayer formation of the sorbed molecules.

The Freundlich isotherm model parameters were $K_{\mathrm{f}}=2.076 \times 10^{-11} \cdot \mathrm{L}^{5.365} / \mathrm{g}$ bioadsorbent with $\mathrm{n}=0.186$. The constant $\mathrm{K}_{\mathrm{f}}$ indicates the relative adsorption capacity of the bioadsorbent. The adsorption exponent $\mathrm{n}$ represent the favorability of the adsorption process [75]. The higher the value of $\mathrm{n}$ for a specific FFA adsorbent materials shows that it can accommodate more FFA by increasing the residual concentration [65]. Adsorbent materials with $n$ values in the range $2-10$ are considered good adsorbent, while moderately difficult adsorbents have values in the range 1-2. Materials with values less than one are characterized by poor adsorptive potential. The magnitude of $n(0.186)$ in the current study indicates a poor adsorption process. The fitting of Freundlich isotherm proposes that interactions occur between FFA and alkali residues, further, different sites with several adsorption energies are involved. This is also confirmed by the $b_{T}$ value obtained from the Temkin model $\left(b_{T}=125 \mathrm{~J} / \mathrm{mol} \cdot \mathrm{K}\right.$ and thus $\left.\mathrm{B}=19.69 \mathrm{~J} / \mathrm{mol}\right)$, which indicates moderate physical interactions between the residues surface and the adsorbent.

\section{Conclusions}

In the presented study, delignified olive cake was successfully produced and evaluated as a potential bioadsorbent for biodiesel purification. The properties of crud biodiesel, wet purified biodiesel, and dry purified biodiesel with alkali residues were evaluated following an international standard. Dry purification of biodiesel using the produced bioadsorbent turn better biodiesel properties with a higher yield compared with wet purified samples. Further, the adsorbent showed much better durability and regeneration characteristics compared to the reported bioadsorbent in the literature. The produced alkali residues bioadsorbent was able to remove $99.7 \%$ of the free glycerin and $29.8 \%$ of the FFA which is comparable and even better than some available bioadsorbent in the literature. The capability of using the waste streams of olive cake as a bioadsorbent for biodiesel purification highlights the valorization of these streams and can reduce 
the environmental burden of the waste of the olive industry. Finally, the analysis of the experimental isothermal equilibrium data sets of FFA adsorption onto alkali residues revealed that data are well represented by nonlinear Freundlich and Temkin isotherms.

Author Contributions: Conceptualization, M.A. (Mohammad Alnaief) and Z.A.-h.; methodology, A.S.; M.A. (Mohammad Alnaief); validation, M.A. (Malek Alkasrawi), Z.A.-h., and M.A.-S.; formal analysis, Z.A.-h.; investigation, A.S.; resources, M.A. (Mohammad Alnaief); data curation, M.A.-S., M.A. (Malek Alkasrawi) and I.A.; writing—original draft preparation, M.A. (Mohammad Alnaief); writing-review and editing, M.A. (Mohammad Alnaief), Z.A.-h.; I.A. visualization, M.A. (Mohammad Alnaief); supervision, Z.A.-h., M.A. (Mohammad Alnaief); project administration, Z.A.-h.; funding acquisition, Z.A.-h.; M.A. (Mohammad Alnaief). All authors have read and agreed to the published version of the manuscript.

Funding: This research received no external funding.

Conflicts of Interest: The authors declare no conflict of interest.

\section{References}

1. Dash, S.K.; Lingfa, P. A Review on Production of Biodiesel Using Catalyzed Transesterification; AIP Publishing LLC: Melville, NY, USA, 2017; Volume 1859, p. 020100.

2. Mishra, V.K.; Goswami, R. A review of production, properties and advantages of biodiesel. Biofuels 2018, 9, 273-289. [CrossRef]

3. Sandouqa, A.; Al-Hamamre, Z.; Asfar, J. Preparation and performance investigation of a lignin-based solid acid catalyst manufactured from olive cake for biodiesel production. Renew. Energy 2019, 132, 667-682. [CrossRef]

4. Chozhavendhan, S.; Singh, M.V.P.; Fransila, B.; Kumar, R.P.; Devi, G.K. A review on influencing parameters of biodiesel production and purification processes. Curr. Res. Green Sustain. Chem. 2020, 1-2, 1-6. [CrossRef]

5. Fonseca, J.M.; Teleken, J.G.; Almeida, V.d.C.; Silva, C.d. Biodiesel from waste frying oils: Methods of production and purification. Energy Convers. Manag. 2019, 184, 205-218. [CrossRef]

6. Salameh, T.; Tawalbeh, M.; Al-Shannag, M.; Saidan, M.; Melhem, K.B.; Alkasrawi, M. Energy saving in the process of bioethanol production from renewable paper mill sludge. Energy 2020, 196, 117085. [CrossRef]

7. Atadashi, I.M.; Aroua, M.K.; Aziz, A.A. Biodiesel separation and purification: A review. Renew. Energy 2011, 36, 437-443. [CrossRef]

8. $\quad$ Baroutian, S.; Shahbaz, K.; Mjalli, S.F.; Alnashef, M.I.; Hashim, A.M. Adsorptive removal of residual catalyst from palm biodiesel: Application of response surface methodology. Hem. Ind. 2012, 66, 373-380. [CrossRef]

9. Šalić, A.; Tušek, A.J.; Gojun, M.; Zelić, B. Biodiesel purification in microextractors: Choline chloride based deep eutectic solvents vs. water. Sep. Purif. Technol. 2020, 242, 116783. [CrossRef]

10. Stojković, I.J.; Stamenković, O.S.; Povrenović, D.S.; Veljković, V.B. Purification technologies for crude biodiesel obtained by alkali-catalyzed transesterification. Renew. Sustain. Energy Rev. 2014, 32, 1-15. [CrossRef]

11. Wall, J.; Van Gerpen, J.; Thompson, J. Soap and glycerin removal from biodiesel using waterless processes. Trans. ASABE 2011, 54, 535-541. [CrossRef]

12. Atadashi, I.M.; Aroua, M.K.; Aziz, A.R.A.; Sulaiman, N.M.N. High quality biodiesel obtained through membrane technology. J. Membr. Sci. 2012, 421-422, 154-164. [CrossRef]

13. Manuale, D.L.; Greco, E.; Clementz, A.; Torres, G.C.; Vera, C.R.; Yori, J.C. Biodiesel purification in one single stage using silica as adsorbent. Chem. Eng. J. 2014, 256, 372-379. [CrossRef]

14. Manuale, D.L.; Mazzieri, V.M.; Torres, G.; Vera, C.R.; Yori, J.C. Non-catalytic biodiesel process with adsorption-based refining. Fuel 2011, 90, 1188-1196. [CrossRef]

15. Faccini, C.S.; Cunha, M.E.d.; Moraes, M.S.A.; Krause, L.C.; Manique, M.C.; Rodrigues, M.R.A.; Benvenutti, E.V.; Caramão, E.B. Dry washing in biodiesel purification: A comparative study of adsorbents. J. Braz. Chem. Soc. 2011, 22, 558-563. [CrossRef]

16. He, H.; Guo, X.; Zhu, S. Comparison of membrane extraction with traditional extraction methods for biodiesel production. J. Am. Oil Chem. Soc. 2006, 83, 457-460. [CrossRef]

17. Banga, S.; Varshney, P.; Kumar, N.; Pal, M. Optimization of parameters for purification of jatropha curcas based biodiesel using organic adsorbents. Int. J. Renew. Energy Res. (IJRER) 2014, 4, 598-603.

18. Okumuş, Z.Ç.; Doğan, T.H.; Temur, H. Removal of water by using cationic resin during biodiesel purification. Renew. Energy 2019, 143, 47-51. [CrossRef]

19. Rudiyanto, B.; Andrianto, M.; Susmiati, Y.; Pambudi, N.A.; Riyanto. Optimization and Validation of Hydrated Magnesium Silicate on Dry Washing Purification Biodiesel Using Response Surface Methodology. Energy Procedia 2019, 158, 333-338. [CrossRef]

20. Schabort, C.; Visser, H.; Venter, R.; Marx, S. Biodiesel production from butter factory effluent. Afr. J. Biotechnol. 2014, 13, 897-904.

21. Sim, S.F.; Lee, T.Z.E.; Lu, N.A.L.M.I.; Mohamed, M. Modified coconut copra residues as a low cost biosorbent for adsorption of humic substances from peat swamp runoff. BioResources 2014, 9, 952-968. [CrossRef]

22. Saleh, J.; Dube, M.A.; Tremblay, A.Y. Effect of soap, methanol, and water on glycerol particle size in biodiesel purification. Energy Fuels 2010, 24, 6179-6186. [CrossRef] 
23. Avinash, A.; Murugesan, A. Judicious Recycling of Biobased Adsorbents for Biodiesel Purification: A Critical Review. Environ. Prog. Sustain. Energy 2019, 38, e13077. [CrossRef]

24. Fadhil, A.B.; Dheyab, M.M.; Abdul-Qader, A.-Q.Y. Purification of biodiesel using activated carbons produced from spent tea waste. J. Assoc. Arab Univ. Basic Appl. Sci. 2012, 11, 45-49. [CrossRef]

25. Rachmat, D.; Agustin, A.D.; Risanti, D.D. Purification of Biodiesel Using Activated Carbon Produced from Cocoa Pod Husk. E3s Web Conf. 2018, 42. [CrossRef]

26. Marwaha, A.; Rosha, P.; Mohapatra, S.K.; Mahla, S.K.; Dhir, A. Waste materials as potential catalysts for biodiesel production: Current state and future scope. Fuel Process. Technol. 2018, 181, 175-186. [CrossRef]

27. Jun, K.C.; Abdul Raman, A.A.; Buthiyappan, A. Treatment of oil refinery effluent using bio-adsorbent developed from activated palm kernel shell and zeolite. RSC Adv. 2020, 10, 24079-24094. [CrossRef]

28. Gomes, M.G.; Santos, D.Q.; Morais, L.C.d.; Pasquini, D. Purification of biodiesel by dry washing, employing starch and cellulose as natural adsorbents. Fuel 2015, 155, 1-6. [CrossRef]

29. Noori, M.S.; Karimi, K. Chemical and structural analysis of alkali pretreated pinewood for efficient ethanol production. RSC Adv. 2016, 6, 65683-65690. [CrossRef]

30. Noori, M.S.; Karimi, K. Detailed study of efficient ethanol production from elmwood by alkali pretreatment. Biochem. Eng. J. 2016, 105, 197-204. [CrossRef]

31. Espadas-Aldana, G.; Vialle, C.; Belaud, J.-P.; Vaca-Garcia, C.; Sablayrolles, C. Analysis and trends for Life Cycle Assessment of olive oil production. Sustain. Prod. Consum. 2019, 19, 216-230. [CrossRef]

32. Khounani, Z.; Hosseinzadeh-Bandbafha, H.; Moustakas, K.; Talebi, A.F.; Goli, S.A.H.; Rajaeifar, M.A.; Khoshnevisan, B.; Jouzani, G.S.; Peng, W.; Kim, K.-H.; et al. Environmental life cycle assessment of different biorefinery platforms valorizing olive wastes to biofuel, phosphate salts, natural antioxidant, and an oxygenated fuel additive (triacetin). J. Clean. Prod. 2021, $278,123916$. [CrossRef]

33. Lafka, T.-I.; Lazou, A.E.; Sinanoglou, V.J.; Lazos, E.S. Phenolic and antioxidant potential of olive oil mill wastes. Food Chem. 2011, 125, 92-98. [CrossRef]

34. Al-Addous, M.; Alnaief, M.; Class, C.; Nsair, A.; Kuchta, K.; Alkasrawi, M. Technical Possibilities of Biogas Production from Olive and Date Waste in Jordan. BioResources 2017, 12, 9383-9395.

35. Aragón, J.; Palancar, M. Improlive 2000. In Present and Future of Alperujo; Editorial Complutense: Madrid, Spain, 2001.

36. Buckland, G.; González, C.A. Chapter 72-Trends in Olive Oil Production, Supply and Consumption in Mediterranean Countries from 1961 to the Present Day. In Olives and Olive Oil in Health and Disease Prevention; Preedy, V.R., Watson, R.R., Eds.; Academic Press: San Diego, CA, USA, 2010; pp. 689-698. ISBN 978-0-12-374420-3.

37. Al-Widyan, M.I.; Tashtoush, G.; Khdair, A.I. Briquettes of olive cake as a potential source of thermal energy. J. Solid Waste Technol. Manag. 2002, 28, 51-59.

38. Gálvez-Pérez, A.; Pérez, A.; Calero, M.; Martín-Lara, M.A.; Blázquez, G. Integral exploitation from olive cake for energy production in a biorefinery scheme. Process. Saf. Environ. Prot. 2019, 131, 135-143. [CrossRef]

39. Fernández-González, R.; Martín-Lara, M.A.; Blázquez, G.; Tenorio, G.; Calero, M. Hydrolyzed olive cake as novel adsorbent for copper removal from fertilizer industry wastewater. J. Clean. Prod. 2020, 268, 121935. [CrossRef]

40. Song, S.; Saman, N.; Johari, K.; Mat, H. Removal of mercury (II) from aqueous solution by using rice residues. J. Teknol. 2013, 63. [CrossRef]

41. Gautam, R.K.; Mudhoo, A.; Lofrano, G.; Chattopadhyaya, M.C. Biomass-derived biosorbents for metal ions sequestration: Adsorbent modification and activation methods and adsorbent regeneration. J. Environ. Chem. Eng. 2014, 2, 239-259. [CrossRef]

42. Velazquez-Jimenez, L.H.; Pavlick, A.; Rangel-Mendez, J.R. Chemical characterization of raw and treated agave bagasse and its potential as adsorbent of metal cations from water. Ind. Crop. Prod. 2013, 43, 200-206. [CrossRef]

43. Kong, Z.; Li, X.; Tian, J.; Yang, J.; Sun, S. Comparative study on the adsorption capacity of raw and modified litchi pericarp for removing Cu (II) from solutions. J. Environ. Manag. 2014, 134, 109-116. [CrossRef] [PubMed]

44. Rafatullah, M.; Sulaiman, O.; Hashim, R.; Ahmad, A. Adsorption of methylene blue on low-cost adsorbents: A review. J. Hazard. Mater. 2010, 177, 70-80. [CrossRef] [PubMed]

45. Hor, K.Y.; Chee, J.M.C.; Chong, M.N.; Jin, B.; Saint, C.; Poh, P.E.; Aryal, R. Evaluation of physicochemical methods in enhancing the adsorption performance of natural zeolite as low-cost adsorbent of methylene blue dye from wastewater. J. Clean. Prod. 2016, 118, 197-209. [CrossRef]

46. Iakovleva, E.; Maydannik, P.; Ivanova, T.V.; Sillanpää, M.; Tang, W.Z.; Mäkilä, E.; Salonen, J.; Gubal, A.; Ganeev, A.A.; Kamwilaisak, K. Modified and unmodified low-cost iron-containing solid wastes as adsorbents for efficient removal of as (III) and as (V) from mine water. J. Clean. Prod. 2016, 133, 1095-1104. [CrossRef]

47. Sandouqa, A.; Al-Shannag, M.; Al-Hamamre, Z. Biodiesel purification using biomass-based adsorbent manufactured from delignified olive cake residues. Renew. Energy 2020, 151, 103-117. [CrossRef]

48. ASTM D974-14e2. Standard Test Method for Acid and Base Number by Color-Indicator Titration; ASTM International: West Conshohocken, PA, USA, 2014.

49. GB/T 5530-2005 Animal and Vegetable Fats and Oils. Determination of Acid Value and Acidity. 2005. Available online: https:/ / www.chinesestandard.net/PDF/English.aspx/GBT5530-2005 (accessed on 20 October 2020). 
50. ASTM D445-06. Standard Test Method for Kinematic Viscosity of Transparent and Opaque Liquids (and Calculation of Dynamic Viscosity); ASTM International: West Conshohocken, PA, USA, 2006.

51. ASTM D1959-97. Standard Test Method for Iodine Value of Drying Oils and Fatty Acids (Withdrawn 2006); ASTM International: West Conshohocken, PA, USA, 1997.

52. IUPAC. Standard Methods for the Analysis of Oils, Fats and Derivatives: 1st Supplement to the 7th Edition (IUPAC Chemical Data); International Union of Pure and Applied Chemistry, Blackwell: Oxford, UK, 1992; Available online: https://old.iupac.org/ publications/books/ISBN0632033371_compress.pdf (accessed on 18 September 2020).

53. ASTM D1962-85. Standard Test Method for Saponification Value of Drying Oils, Fatty Acids, and Polymerized Fatty Acids (Withdrawn 2004); ASTM International: West Conshohocken, PA, USA, 1995.

54. Ouaini, R.; Estephan, N.; Chébib, H.; Rutledge, D.; Medawar, S.; Daoud, R.; Ouaini, N. Chemical Composition of Olive Cakes Resulting from Various Mills in Lebanon. Agrochimica 2010, 54, 321-330.

55. Standard, T. T 211 Om-07. Ash in Wood, Pulp, Paper and Paperboard: Combustion at 525 C; TAPPI Standard: Peachtree Corners, GA, USA, 2007.

56. ASTM E1721-01. Standard Test Method for Determination of Acid-Insoluble Residue in Biomass; ASTM International: West Conshohocken, PA, USA, 2020.

57. Vicentim, M.; Sousa, M.; da Silva, V.; Mateus, V.; Rodrigues, J.; da Cunha, V. Water content determination in biodiesel: optimization of methodology in coulometric Karl Fischer titration. In Biofuels; ASTM International: West Conshohocken, PA, USA, 2011.

58. Sarioglu, M.; Atay, Ü.; Cebeci, Y. Removal of copper from aqueous solutions by phosphate rock. Desalination 2005, 181, 303-311. [CrossRef]

59. Temkin, M. Kinetics of ammonia synthesis on promoted iron catalysts. Acta Physiochim. URSS 1940, 12, 327-356.

60. Fadhil, A.B.; Abdulahad, W.S. Transesterification of mustard (Brassica nigra) seed oil with ethanol: Purification of the crude ethyl ester with activated carbon produced from de-oiled cake. Energy Convers. Manag. 2014, 77, 495-503. [CrossRef]

61. Saengprachum, N.; Pengprecha, S.; Poothongkam, J. Glycerine removal in biodiesel purification process by adsorbent from rice husk. Int. J. Sci. Eng. Technol. 2013, 2, 474-478.

62. Manique, M.C.; Faccini, C.S.; Onorevoli, B.; Benvenutti, E.V.; Caramão, E.B. Rice Husk Ash as an Adsorbent for Purifying Biodiesel from Waste Frying Oil. Fuel 2012, 92, 56-61. [CrossRef]

63. Farid, M.A.A.; Hassan, M.A.; Taufiq-Yap, Y.H.; Shirai, Y.; Hasan, M.Y.; Zakaria, M.R. Waterless purification using oil palm biomass-derived bioadsorbent improved the quality of biodiesel from waste cooking oil. J. Clean. Prod. 2017, 165, 262-272. [CrossRef]

64. Alves, M.J.; Cavalcanti, Í.V.; de Resende, M.M.; Cardoso, V.L.; Reis, M.H. Biodiesel dry purification with sugarcane bagasse. Ind. Crop. Prod. 2016, 89, 119-127. [CrossRef]

65. Fadhil, A.B.; Saeed, L.I. Sulfonated tea waste: A low-cost adsorbent for purification of biodiesel. Int. J. Green Energy 2016, 13, 110-118. [CrossRef]

66. Özgül-Yücel, S.; Türkay, S. Purification of FAME by rice hull ash adsorption. J. Am. Oil Chem. Soc. 2003, 80, 373-376. [CrossRef]

67. Subramanyam, B.; Das, A. Linearised and non-linearised isotherm models optimization analysis by error functions and statistical means. J. Environ. Health Sci. Eng. 2014, 12, 92. [CrossRef]

68. Salihi, I.U.; Bala, N.; Danlami, N.; Abdulfatah, A. Comparison of Linear and Non-Linear Methods of Freundlich and Langmuir Isotherm Models for the Adsorption of Lead Using Sugarcane Bagasse. Noble Int. J. Sci. Res. 2017, 1, 69-72.

69. Bolster, C.H.; Hornberger, G.M. On the use of linearized Langmuir equations. Soil Sci. Soc. Am. J. 2007, 71, 1796-1806. [CrossRef]

70. Huang, Y.-T.; Shih, M.-C. Effect of linearized expressions of Langmuir equations on the prediction of the adsorption of methylene blue on rice husk. Source Int. J. Sci. Res. Publ. 2016, 6, 549-554.

71. Khambhaty, Y.; Mody, K.; Basha, S.; Jha, B. Pseudo-second-order kinetic models for the sorption of Hg (II) onto dead biomass of marine Aspergillus niger: Comparison of linear and non-linear methods. Colloids Surf. A Physicochem. Eng. Asp. 2008, 328, 40-43. [CrossRef]

72. Harter, R.D. Curve-fit errors in Langmuir adsorption maxima. Soil Sci. Soc. Am. J. 1984, 48, 749-752. [CrossRef]

73. Ho, Y.S. Selection of optimum sorption isotherm. Carbon 2004, 42, 2115-2116. [CrossRef]

74. Ho, Y.-S.; Chiu, W.-T.; Wang, C.-C. Regression analysis for the sorption isotherms of basic dyes on sugarcane dust. Bioresour. Technol. 2005, 96, 1285-1291. [CrossRef] [PubMed]

75. Liu, Y.; Liu, Y.-J. Biosorption Isotherms, Kinetics and Thermodynamics. Sep. Purif. Technol. 2008, 61, 229-242. [CrossRef] 